\title{
Periurethral pseudoabscess secondary to injection of an intraurethral bulking agent
}

\author{
Deirdre Mary Fanning, Hugh Flood \\ Urology Department, Midwestern Regional Hospital, Limerick, Ireland
}

Correspondence to Miss Deirdre Mary Fanning, fanningdee@yahoo.co.uk

\section{DESCRIPTION}

An 85-year-old lady returned to the urology clinic for review 10 months postcystoscopically guided proximal urethral Zuidex injection for the treatment of stress urinary incontinence. Zuidex is a combination of dextranomer and hyaluronic acid. It is used as a minimally invasive alternative to surgical stress urinary incontinence procedures. She had urinary urgency and a tenderness in the vaginal region. Clinical inspection revealed a periurethral erythematous, warm, tender swelling; causing apparent outlet obstruction (figure 1). A transvaginal puncture

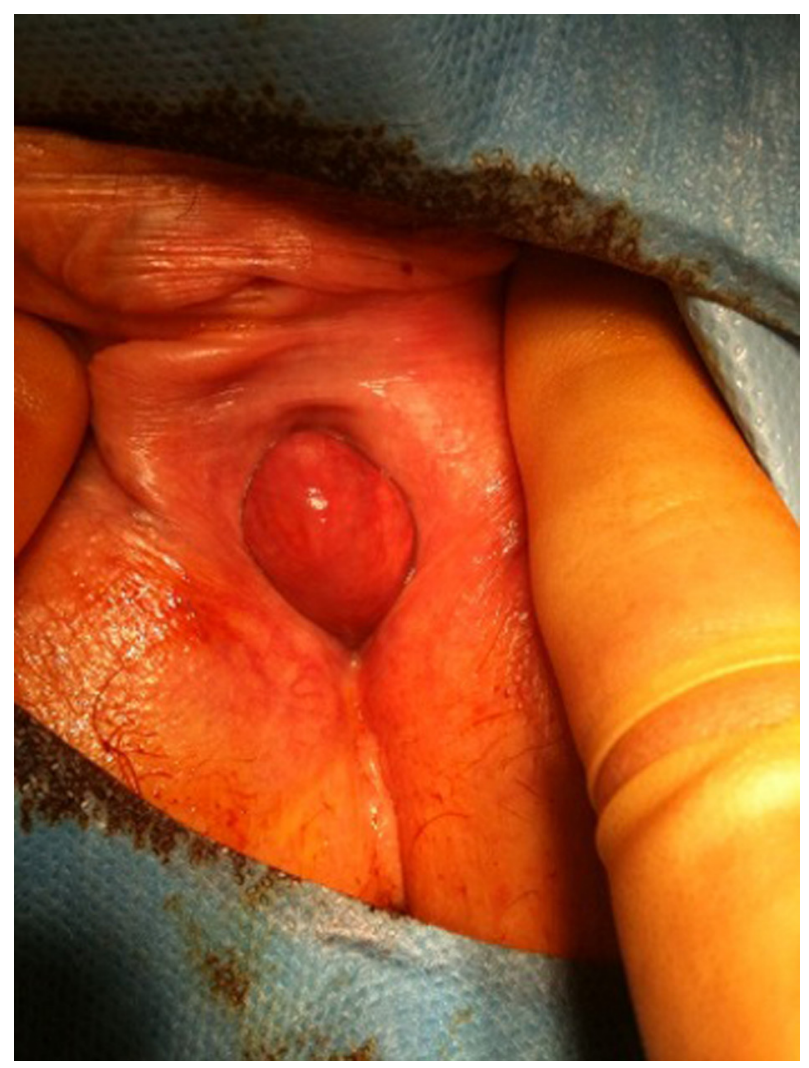

Figure 1 A fluctuant mass is clearly visible protruding from the introitus. The external urethral meatus is placed at the most anterior aspect of the pseudoabscess. was performed under aseptic technique (figure 2). Five millilitre of sterile pus was withdrawn. The procedure was well tolerated. The pseudoabscess did not recur. Postprocedure however, the stress urinary incontinence deteriorated. The reported incidence of pseudoabscess formation following Zuidex injection varies from $10^{1}$ to $15 \% .^{2}$ It does not appear to be related to the volume of Zuidex injected. They can present up to 13 months postinjection. ${ }^{1}$ Periurethral pseudoabscesses very rarely resolve spontaneously and often require multiple operative interventions.

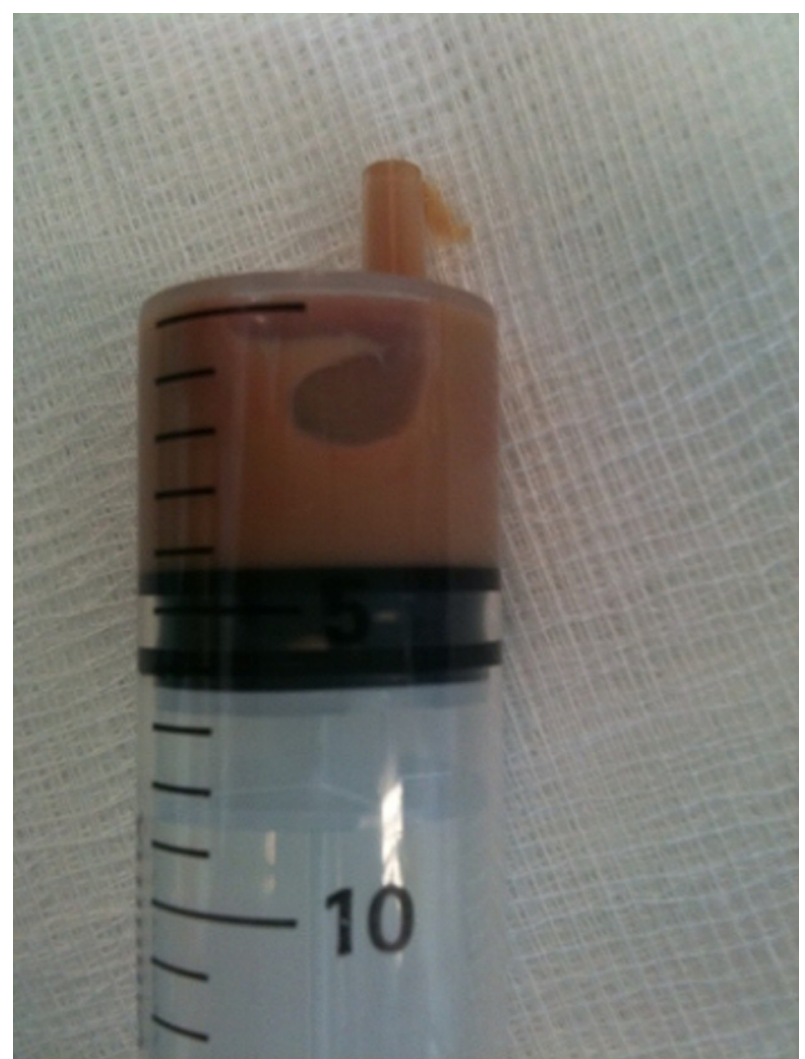

Figure 2 Approximately $5 \mathrm{mls}$ of purulent appearing material was aspirated. 


\section{BMJ Case Reports}

\section{Competing interests None.}

Patient consent Obtained.

\section{REFERENCES}

1. Lightner DJ, Fox J, Klingele C. Cystoscopic injections of dextranomer hyaluronic acid into proximal urethra for urethral incompetence: efficacy and adverse outcomes. Urology 2010;75:1310-4.
2. Lightner D, Rovner E, Corcos J, et al. Randomized controlled multisite trial of injected bulking agents for women with intrinsic sphincter deficiency: midurethral injection of Zuidex via the Implacer versus proximal urethral injection of Contigen cystoscopically. Urology 2009;74:771-5.

This pdf has been created automatically from the final edited text and images.

Copyright 2011 BMJ Publishing Group. All rights reserved. For permission to reuse any of this content visit http://group.bmj.com/group/rights-licensing/permissions.

BMJ Case Report Fellows may re-use this article for personal use and teaching without any further permission.

Please cite this article as follows (you will need to access the article online to obtain the date of publication).

Fanning DM, Flood H. Periurethral pseudoabscess secondary to injection of an intraurethral bulking agent. BMJ Case Reports 2011; 10.1136/bcr.08.2011.4719, Published XXX

Become a Fellow of BMJ Case Reports today and you can:

- Submit as many cases as you like

- Enjoy fast sympathetic peer review and rapid publication of accepted articles

- Access all the published articles

- Re-use any of the published material for personal use and teaching without further permission

For information on Institutional Fellowships contact consortiasales@bmjgroup.com

Visit casereports.bmi.com for more articles like this and to become a Fellow 